\title{
Troponin Elevation in Sickle Cell Disease
}

\author{
Nuri I. Akkus ${ }^{\text {a }}$ Saurabh Rajpal ${ }^{b}$ Jeffrey Hilbun ${ }^{b}$ Ashish Dwary ${ }^{c}$ \\ Thomas R. Smith ${ }^{b}$ George Mina ${ }^{b}$ Pratap C. Reddy \\ ${ }^{\mathrm{a} D i v i s i o n}$ of Cardiology, VAMC, Oklahoma City, OK, USA; ${ }^{\mathrm{b}}$ Division of Cardiology, Louisiana State University Health \\ Sciences Center, Shreveport, LA, USA; 'Department of Medicine, Louisiana State University Health Sciences Center, \\ Shreveport, LA, USA
}

\section{Highlights of the Study}

- Troponin elevation does not appear to be unusual in patients with sickle cell pain crisis.

- Troponin elevation in sickle cell patients correlated with hemolytic burden and pulmonary hypertension rather than with traditional risk factors for coronary artery disease.

- In addition to sickling resulting in microvascular occlusion, increased hemolytic burden in sickle cell disease most likely leads to vasculopathy, endothelial dysfunction, decrease in nitric oxide, vasoconstriction, and occlusion of small vessels resulting in myocardial cell damage, microinfarcts, and release of troponin.

\section{Keywords}

Troponin elevation · Sickle cell disease · Pulmonary hypertension

\section{Abstract \\ Objective: Sickle cell disease is associated with cardiovascu- lar abnormalities. Troponin is not typically measured in this population, and thus the significance of abnormal levels of troponin is unknown. We wanted to evaluate the use of tro- ponin and factors that predispose troponin elevation in pa- tients admitted with sickle cell pain crisis (SCPC). Methods: We reviewed data of consecutive patients admitted to a ter- tiary care hospital between 2006 and 2011 with a diagnosis of SCPC. Subjects with elevated troponin (ET) (troponin I $>0.04 \mathrm{ng} / \mathrm{mL}$ ) were compared with those with normal tropo- nin (NT) for demographics, risk factors, presence of echocar- diography-derived tricuspid regurgitant jet velocity (TRV) $\geq 3$ $\mathrm{m} / \mathrm{s}$ suggesting pulmonary hypertension, and laboratory tests. The Mann-Whitney U test was used to compare groups. Results: Two hundred eighty-three of 724 patients admitted}

karger@karger.com www.karger.com/mpp

Karger $\stackrel{\text { ' }}{=}$
C 2021 The Author(s)

Published by S. Karger AG, Basel

This is an Open Access article licensed under the Creative Commons Attribution-NonCommercial-4.0 International License (CC BY-NC) (http://www.karger.com/Services/OpenAccessLicense), applicable to the online version of the article only. Usage and distribution for commercial purposes requires written permission. with SCPC had chest pain. Troponin I was measured in 63 patients: 51 had NT and 12 had ET ranging from 0.06 to 3.42 $\mathrm{ng} / \mathrm{ml}$. ET was associated lower hemoglobin $(p=0.02)$, lower hematocrit $(p=0.02)$, lower platelet number $(p<0.001)$, higher LDH ( $p=0.012)$, higher AST levels ( $p=0.004)$, higher bilirubin levels $(p=0.006)$, and TRV $\geq 3 \mathrm{~m} / \mathrm{s}(p=0.028)$. Conclusions: Troponin was measured in $<10 \%$ of patients with SCPC, and 1 out of 5 of them had ET. Troponin elevation was not associated with traditional cardiovascular risk factors but was associated with lower hematocrit, elevated LDH, bilirubin levels, and TRV $\geq 3 \mathrm{~m} / \mathrm{s}$.

(C) 2021 The Author(s) Published by S. Karger AG, Basel

\section{Introduction}

Sickle cell disease (SCD) is an autosomal recessive abnormality of the beta-globin chain of hemoglobin ( $\mathrm{Hgb}$ ), resulting in decreased deformability and increased adhesion of the sickle cells causing microvascular occlusion and hemolytic anemia [1]. As patients with SCD age and 
Table 1. Comparison of demographic and laboratory information between the 2 groups

\begin{tabular}{|c|c|c|c|}
\hline Demographics & Negative troponin & Elevated troponin & $p$ value \\
\hline Age, median (IQR), years & $30(24-37)$ & $33(21.25-44.25)$ & 0.719 \\
\hline \multicolumn{4}{|l|}{ Sex, $n \%$} \\
\hline Males & $31(60.8)$ & $7(58.3)$ & \multirow{2}{*}{$>0.999$} \\
\hline Females & $20(39.2)$ & $5(41.7)$ & \\
\hline \multicolumn{4}{|l|}{ History, $n(\%)$} \\
\hline HTN & $18(35.3)$ & $8(66.7)$ & 0.058 \\
\hline $\mathrm{DM}$ & $2(3.9)$ & $1(8.3)$ & 0.476 \\
\hline Smoking & $19(37.3)$ & $1(8.3)$ & $>0.999$ \\
\hline CVA & $8(15.7)$ & $9(21.4)$ & $>0.999$ \\
\hline $\mathrm{CHF}$ & $8(15.7)$ & $2(16.7)$ & $>0.999$ \\
\hline Pulmonary HTN & $9(17.6)$ & $6(50)$ & 0.028 \\
\hline \multicolumn{4}{|l|}{ Laboratory data } \\
\hline GFR $<60 \mathrm{~mL} / \mathrm{min}, n(\%)$ & $3(5.9)$ & $4(33.3)$ & 0.021 \\
\hline Creatinine, median (IQR), mg/dL & $0.6(0.5-0.8)$ & $1.05(0.5-2.225)$ & 0.09 \\
\hline $\mathrm{WBCs}$, mean $\pm \mathrm{SD}, \mathrm{k} / \mu \mathrm{L}$ & $15.345 \pm 5.231$ & $14.962 \pm 5.135$ & 0.82 \\
\hline Hgb, median (IQR), G/dL & $8.7(7.7-10.1)$ & $7.35(6.72-8.17)$ & 0.02 \\
\hline HCT, median (IQR), \% & $25.6(22.2-29.9)$ & $20.35(18.72-23.57)$ & 0.02 \\
\hline MCV, median (IQR), fL & $90.1(85.6-93.1)$ & $91.85(85.02-104.17)$ & 0.377 \\
\hline Platelets, median (IQR), k/ $\mu \mathrm{L}$ & $376(276-518)$ & $216(176-323)$ & $<0.001$ \\
\hline $\mathrm{MPV}$, mean $\pm \mathrm{SD}, \mathrm{fL}$ & $8.256 \pm 0.766$ & $8.808 \pm 0.703$ & 0.027 \\
\hline Reticulocytes, median (IQR), \% & $6.15(1.09-10.15)$ & $8.6(7.15-11.05)$ & 0.106 \\
\hline RPI, median (IQR), \% & $3.1(1.82-4.6)$ & $1.5(0.82-2.52)$ & 0.054 \\
\hline LDH, median (IQR), U/L & $403(220-583)$ & $643(505-1,270)$ & 0.012 \\
\hline AST, median (IQR), U/L & $39(21-64)$ & $78(43-111)$ & 0.004 \\
\hline ALT, median(IQR), U/L & $26(16-41)$ & $31(21-43)$ & 0.473 \\
\hline Tbil, median (IQR), mg/dL & $1.8(1.07-3)$ & $3.6(2.1-6.4)$ & 0.006 \\
\hline
\end{tabular}

HTN, hypertension; DM, diabetes mellitus; CVA, cerebrovascular accident; CHF, congestive heart failure; pulmonary HTN, pulmonary hypertension; GFR, glomerular filtration rate; WBC, white blood cell; Hgb, hemoglobin; HCT, hematocrit; MCV, mean corpuscular volume; MPV, mean platelet volume; RPI, reticulocyte production index; LDH, lactate dehydrogenase; AST, aspartate aminotransferase; ALT, alanine aminotransaminase; Tbil, total bilirubin.

survive into adulthood, cardiovascular complications including pulmonary hypertension [2], stroke [3], and diastolic and left ventricular dysfunction become increasingly more evident [4]. Several studies have shown that patients with acute sickle cell pain crisis (SCPC) have ECG changes [5, 6]. Troponin is a sensitive biomarker of myocardial ischemia and injury. Troponin elevation can occur in settings of hypoxia, anemia, sepsis, acidosis, renal failure, and cor pulmonale [7] in addition to acute coronary syndromes. Elevation of troponin levels with findings of infarct in cardiac MRI has been reported in SCD [7]. Studies on children have also shown nuclear perfusion defects [8]. Although markers of hemolytic anemia in patients with SCD have correlated with pulmonary hypertension $[2,9]$, priapism, leg ulceration, and risk of death [9-11], the prevalence and significance of elevated cardiac troponin is still not well unknown. We attempted to answer this question by evaluating patients with SCD who have sickle cell anemia/Hgb SCD who were admitted to a tertiary care center over a 5-year period with a diagnosis of SCPC.

\section{Materials and Methods}

We retrospectively reviewed data of consecutive patients admitted to a tertiary care hospital between 2006 and 2011 with a diagnosis of SCPC. These patients were identified by cross-referencing the International Classification of Diseases Ninth Revision (ICD-9) code 282.64 which includes sickle cell anemia/Hgb SCD with crisis. Elevated troponin is defined as troponin level with at least 1 value above the 99th percentile of the upper reference limit [12]. Subjects with chest pain and elevated cardiac troponin (ET group, troponin I $>0.04 \mathrm{ng} / \mathrm{mL}$ ) were compared with those with chest pain and normal troponin (NT group, troponin $\mathrm{I}<0.04 \mathrm{ng} /$ $\mathrm{mL}$ ) for age, gender, race, presence of chest pain or dyspnea, ex- 
Table 2. PAP and EF of patients with abnormal troponin

\begin{tabular}{llll}
\hline $\begin{array}{l}\text { Patient } \\
\text { number }\end{array}$ & $\begin{array}{l}\text { Troponin, } \\
\text { ng/mL }\end{array}$ & $\begin{array}{l}\text { Estimated PAP, } \\
\text { mm Hg }\end{array}$ & EF, \% \\
\hline 1 & 1.34 & 67 & 70 \\
2 & 0.16 & 67 & 70 \\
3 & 0.17 & na & na \\
4 & 0.28 & 96 & 65 \\
5 & 1.66 & 90 & 55 \\
6 & 1.05 & na & 60 \\
7 & 0.22 & na & 60 \\
8 & 3.24 & 43 & 50 \\
9 & 2.62 & 18 & 60 \\
10 & 2.1 & na & na \\
11 & 0.05 & 42 & 60 \\
12 & 0.06 & 26 & 60 \\
\hline
\end{tabular}

PAP, pulmonary artery pressure (estimated by echocardiogram); EF, ejection fraction (estimated by echocardiogram); na, not available.

change transfusions, hypertension, diabetes mellitus, smoking, prior coronary artery disease, chronic kidney disease (glomerular filtration rate: $\mathrm{GFR}<60 \mathrm{~mL} / \mathrm{min} / 1.73 \mathrm{~m}^{2}$ ) with the use of the modified Modification in Renal Disease formula, heart failure, echocardiography-derived tricuspid regurgitant jet velocity (TRV) $\geq 3 \mathrm{~m} / \mathrm{s}$ suggestive of pulmonary hypertension, and laboratory tests including Hgb, hematocrit, complete metabolic panel, reticulocyte count, lactate dehydrogenase (LDH), aspartate aminotransferase (AST), alanine aminotransaminase (ALT), and bilirubin levels (Tables 1, 2; Fig. 1).

Statistical analysis was done using SPSS version 17. Continuous data that were normally distributed were displayed as mean \pm standard deviation, and the $t$ test was used for comparison. Continuous data that were not normally distributed were displayed as median and interquartile range, and the Mann-Whitney test was used for comparison. Fisher's exact test was used for categorical data. The hospital's institutional review board approved this study.

\section{Results}

There were 724 SCPC admissions; 283 had chest pain, and among those with chest pain, troponin was measured in 63 patients. Fifty-one patients were in the NT group and 12 patients in the ET group. Troponin I in the ET group ranged from 0.06 to $3.42 \mathrm{ng} / \mathrm{mL}$ with an average of $1.08 \mathrm{ng} / \mathrm{mL}$ (Table 2).

Two patients in the ET group underwent coronary angiogram, which did not reveal obstructive CAD. Elevated troponins were significantly associated with GFR $<60$ $\mathrm{mL} / \mathrm{mi} / 1.73 \mathrm{~m}^{2}(p=0.021)$, lower $\mathrm{Hgb}(p=0.02)$, lower

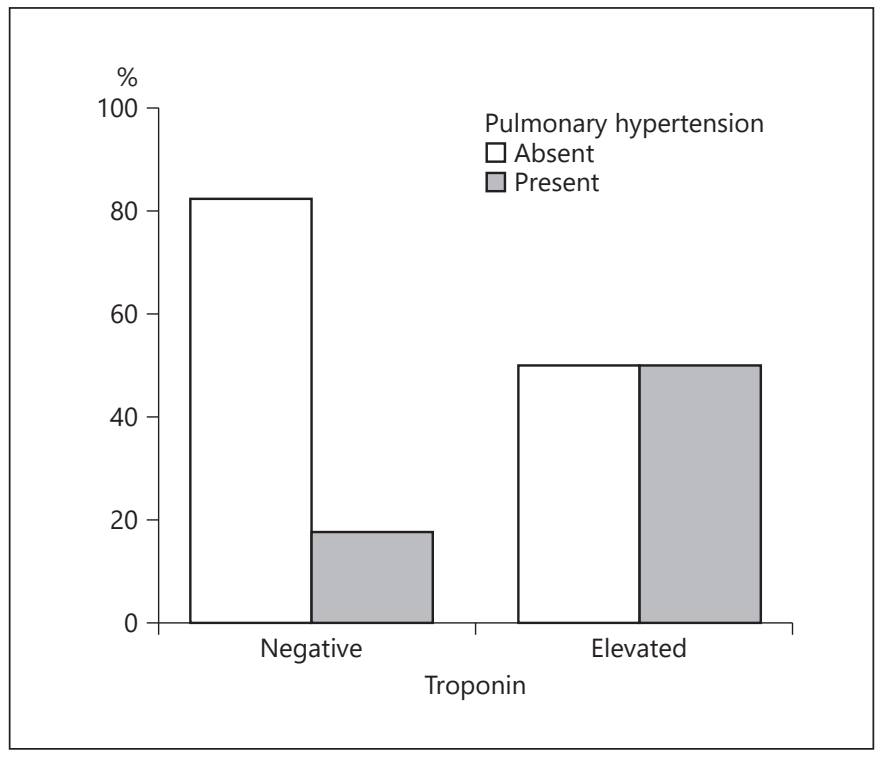

Fig. 1. Relationship between pulmonary hypertension and troponin.

hematocrit $(p=0.02)$, lower platelets $(p<0.001)$, higher mean platelet volume $(p=0.027)$, higher LDH $(p=0.012)$, higher AST $(p=0.004)$, higher bilirubin $(p=0.006)$ (Table 1), and echocardiography-derived TRV $\geq 3 \mathrm{~m} / \mathrm{s}$ ( $p=$ 0.028 ) (Fig. 1,2). Traditional risk factors for CAD such as age, smoking, hypertension, diabetes mellitus, and family history of premature CAD were not significantly different between the 2 groups (Table 1; Fig. 1, 2). GFR $<60$ was also associated with elevation of troponin $(p=0.021)$.

\section{Discussion}

There are limited data in the literature about the clinical significance and causes of troponin elevation in adult sickle cell patients. There are several case reports of myocardial infarction in sickle cell patients without significant coronary artery occlusion [13]. In an autopsy study, the frequency of myocardial infarction was reported to be as much as $9.7 \%$ in the absence of significant obstructive or atherosclerotic lesions [14]. In our study, we had 2 patients who had no significant CAD in angiogram despite significant troponin elevation.

Myocardial ischemia from microvascular coronary obstruction with red blood cell injury sickling during sickle cell crisis is one of the explanations for troponin elevation [15]. We found that troponin elevation correlated with hemolytic burden (low Hgb, increased $\mathrm{LDH}$, and increased bilirubin) (Fig. 1, 2; Table 2). Markers for hemo- 
Fig. 2. Hgb, LDH, and Tbil relationship with troponin. Hgb, hemoglobin; LDH, lactate dehydrogenase; Tbil, total bilirubin.

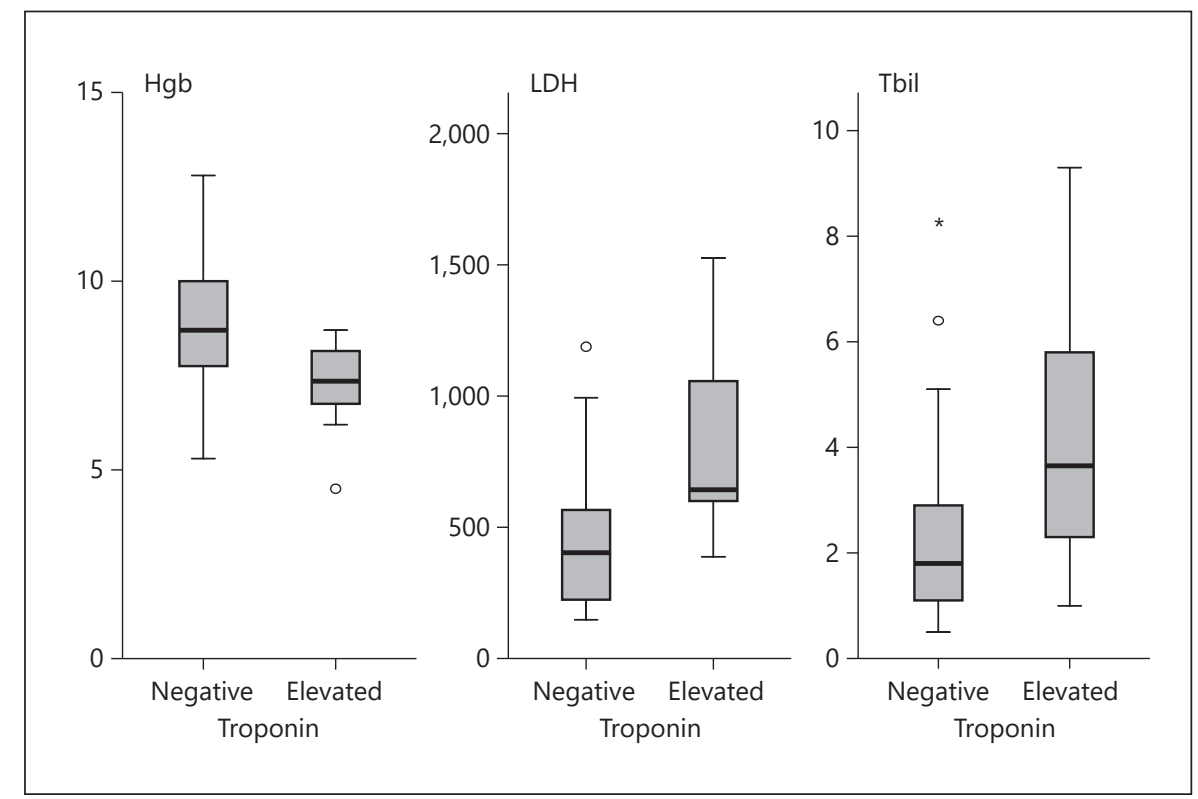

lysis are associated with reduced nitric oxide availability [16], endothelial dysfunction [17], and pulmonary hypertension $[18,19]$ suggesting the link between hemolysis, hemolytic rate, and sickle vasculopathy [20]. In addition to sickling resulting in microvascular occlusion, hemolysis of sickle cells releases cellular components including $\mathrm{Hgb}$ and arginase 1, which catabolize nitric oxide (NO) and activate vascular oxidases that generate superoxide which also scavenges nitric oxide [21]. Increased hemolytic burden in SCD most likely leads to vasculopathy, endothelial dysfunction, decrease in NO, vasoconstriction, and occlusion of small vessels resulting in myocardial cell damage, microinfarcts, and release of troponin.

Echocardiography-derived TRV $\geq 3 \mathrm{~m} / \mathrm{s}$ suggestive of underlying pulmonary hypertension also correlated with troponin elevation. Pulmonary hypertension is one of the major vasculopathic complications of SCD, and mild $\mathrm{PH}$ at steady state was associated with an increased risk of sudden death in adults with SCD (2). In an autopsy study, up to $75 \%$ of SCD patients had histologic pulmonary hypertension [19]. TRV $\geq 3.0 \mathrm{~m} / \mathrm{s}$ has been reported in approximately $10 \%$ of SCD and has the highest risk for death of any measured variable [22]. Acute chest syndrome may induce or worsen pulmonary arterial pressure elevation, and pulmonary hypertension is associated with cardiac biomarker elevation and a higher risk of death [18]. In this study, mean troponin I and BNP levels were $0.03 \mathrm{ng} / \mathrm{mL}$ and $115 \mathrm{pg} / \mathrm{mL}$ and ranged between 0.00 and $0.14 \mathrm{ng} / \mathrm{mL}$ and 34 and $583 \mathrm{pg} / \mathrm{mL}$, respectively. Of note, changes in the pulmonary function test, especially forced expiratory volume 1 , observed as early as in the 7to 14-year age group of SCD patients were suggestive of development of obstructive lung disease in addition to restrictive patterns reported in adults $[23,24]$. Right ventricular failure secondary to an increase in afterload with or without primary pulmonary hypertension in setting of some underlying lung disease could have contributed to elevation of troponin in our study.

AST and bilirubin levels were also elevated in our study. Chronic hemolysis and ineffective erythropoiesis, rather than liver disease, are reported to be the sources of hyperbilirubinemia in SCD $[17,25]$. Erythrocytic glutamate biosynthesis is catalyzed by 3 enzymes in red blood cells, ALT, AST, and glutamine aminohydrolase [26]. We did not observe any significant difference in levels of ALT between the groups and increased levels of AST in the ET group possibly due to increased hemolytic burden.

GFR $<60$ was also associated with elevation of tropo$\operatorname{nin}(p=0.021)$ in the study. Elevations of troponin without acute coronary syndrome have been reported in chronic kidney disease stage 3-5 [27]. However, in our patients, elevation in troponin was not steady; we noticed increase and decrease suggestive of acute changes in troponin levels.

SCD was reported to cause both right and left ventricular systolic and diastolic dysfunction, elevated cardiac output, and cardiomegaly [4] in addition to myocardial ischemia. Measuring troponin levels will also be helpful to identify patients who may have, or will develop, such cardiovascular problems. 
Limitations of our study include the fact that it was a retrospective, single-center study with a limited sample size. Furthermore, blood samples were only taken at the time of SCPC, and troponin was not measured in every patient but only in patients with chest pain; this could have created a selection bias. Another limitation is that we have used echocardiography-derived TRV $\geq 3 \mathrm{~m} / \mathrm{s}$ as an indirect estimation of pulmonary artery pressure, and studies suggest discrepancies between Doppler-estimated and invasively measured pulmonary artery systolic pressure measurements due to imprecise right atrial pressure estimation, suboptimal alignment between the Doppler beam and the regurgitant jet, and the presence of severe tricuspid valve regurgitation [28].

\section{Conclusion}

Prior to our study, the usefulness and correlation of troponin elevation with hemolytic burden, pulmonary hypertension, and traditional cardiac risk factors was not well known. In this retrospective study, we have observed that troponin level was measured in $8.7 \%$ of the patients with SCPC. Among those measured, 19\% of them had significant troponin elevation.

Uniquely in SCD, elevated troponin was not associated with traditional cardiovascular risk factors and obstructive CAD but correlated with indices of hemolytic burden and pulmonary hypertension which are the pos- sible mechanisms how SCD affects the heart. Troponin elevation may be used as a screening tool and a predictor for cardiovascular complications of SCD and pulmonary hypertension which could indicate an increased mortality risk in this population.

\section{Statement of Ethics}

The authors have no ethical conflicts to disclose. This study has been approved by the Institutional Review Board at LSU Health Shreveport.

\section{Conflict of Interest Statement}

The authors have no conflicts of interest to declare.

\section{Funding Sources}

This study received no grant from any funding agency.

\section{Author Contributions}

Nuri I. Akkus and Saurabh Rajpal planned the study and contributed to write the manuscript. Jeffrey Hilbun, Ashish Dwary, and Thomas R. Smith collected the data and contributed to write the manuscript. George Mina did the statistical analysis and contributed to the manuscript. Pratap C. Reddy contributed to the manuscript.

\section{References}

1 Bunn HF. Pathogenesis and treatment of sickle cell disease. N Engl J Med. 1997 Sep 11; 337(11):762-9.

2 Gladwin MT, Sachdev V, Jison ML, Shizukuda Y, Plehn JF, Minter K, et al. Pulmonary hypertension as a risk factor for death in patients with sickle cell disease. N Engl J Med. 2004 Feb 26;350(9):886-95.

3 Ohene-Frempong K, Weiner SJ, Sleeper LA, Miller ST, Embury S, Moohr JW, et al. Cerebrovascular accidents in sickle cell disease: rates and risk factors. Blood. 1998 Jan 1;91(1):288-94.

4 Voskaridou E, Christoulas D, Terpos E. Sickle-cell disease and the heart: review of the current literature. Br J Haematol. 2012 Jun; 157(6):664-73.

5 Norris S, Johnson CS, Haywood LJ. Sickle cell anemia: does myocardial ischemia occur during crisis? J Natl Med Assoc. 1991;83:209-13.

6 Maisel A, Friedman H, Flint L, Koshy M, Prabhu R. Continuous electrocardiographic monitoring in patients with sickle-cell anemia during pain crisis. Clin Cardiol. 1983 Jul;6(7): $339-44$.
7 Pavlů J, Ahmed RE, O’Regan DP, Partridge J, Lefroy DC, Layton DM. Myocardial infarction in sickle-cell disease. Lancet. 2007 Jan 20; 369(9557):246.

8 de Montalembert M, Maunoury C, Acar P, Brousse V, Sidi D, Lenoir G. Myocardial ischaemia in children with sickle cell disease. Arch Dis Child. 2004 Apr;89(4):359-62.

9 Kato GJ, McGowan V, Machado RF, Little JA, Taylor J, Morris CR, et al. Lactate dehydrogenase as a biomarker of hemolysis-associated nitric oxide resistance, priapism, leg ulceration, pulmonary hypertension, and death in patients with sickle cell disease. Blood. 2006 Mar 15;107(6):2279-85.

10 Nolan VG, Adewoye A, Baldwin C, Wang L, Ma Q, Wyszynski DF, et al. Sickle cell leg ulcers: associations with haemolysis and SNPs in Klotho, TEK and genes of the TGF-beta/BMP pathway. Br J Haematol. 2006 Jun;133(5):570-8.

11 Nolan VG, Wyszynski DF, Farrer LA, Steinberg $\mathrm{MH}$. Hemolysis-associated priapism in sickle cell disease. Blood. 2005 Nov 1;106(9): 3264-7.
12 Thygesen K, Alpert JS, White HD. Joint ESC/ ACCF/AHA/WHF Task Force for the Redefinition of Myocardial Infarction. Universal definition of myocardial infarction. Circulation. 2007 Nov 27;116(22):2634-53.

13 Mansi IA, Rosner F. Myocardial infarction in sickle cell disease. J Natl Med Assoc. 2002 Jun; 94(6):448-52.

14 Martin CR, Johnson CS, Cobb C, Tatter D, Haywood LJ. Myocardial infarction in sickle cell disease. J Natl Med Assoc. 1996 Jul;88(7):428-32.

15 Aslam AK, Rodriguez C, Aslam AF, Vasavada BC, Khan IA. Cardiac troponin I in sickle cell crisis. Int J Cardiol. 2009 Mar 20;133(1):138-9.

16 Reiter CD, Wang X, Tanus-Santos JE, Hogg N, Cannon RO3rd, Schechter AN, et al. Cellfree hemoglobin limits nitric oxide bioavailability in sickle-cell disease. Nat Med. 2002 Dec;8(12):1383-9.

17 Gladwin MT, Schechter AN, Ognibene FP, Coles WA, Reiter CD, Schenke WH, et al. Divergent nitric oxide bioavailability in men and women with sickle cell disease. Circulation. 2003 Jan 21;107(2):271-8. 
18 Mekontso Dessap A, Leon R, Habibi A, Nzouakou R, Roudot-Thoraval F, Adnot S, et al. Pulmonary hypertension and cor pulmonale during severe acute chest syndrome in sickle cell disease. Am J Respir Crit Care Med. 2008 Mar 15;177(6):646-53.

19 Vichinsky EP, Neumayr LD, Earles AN, Williams R, Lennette ET, Dean D, et al. Causes and outcomes of the acute chest syndrome in sickle cell disease. National Acute Chest Syndrome Study Group. N Engl J Med. 2000 Jun 22;342(25):1855-65.

20 Kato GJ, Gladwin MT, Steinberg MH. Deconstructing sickle cell disease: reappraisal of the role of hemolysis in the development of clinical subphenotypes. Blood Rev. 2007;21:3747.
21 Gladwin MT, Sachdev V. Cardiovascular abnormalities in sickle cell disease. J Am Coll Cardiol. 2012;59(13):1123-33.

22 Gladwin MT, Barst RJ, Gibbs JS, Hildesheim M, Sachdev V, Nouraie M, et al. Risk factors for death in 632 patients with sickle cell disease in the United States and United Kingdom. PLoS One. 2014 Jul 2;9(7):e99489.

23 Adekile AD, Azab AF, Owayed A, Khadadah $\mathrm{M}$. Correlates of pulmonary function in children with sickle cell disease and elevated fetal hemoglobin. Med Princ Pract. 2018;27(1):4954.

24 Koumbourlis AC. Lung function in sickle cell disease. Paediatr Respir Rev. 2014 Mar;15(1): 33-7.
25 Ebert EC, Nagar M, Hagspiel KD. Gastrointestinal and hepatic complications of sickle cell disease. Clin Gastroenterol Hepatol. 2010 Jun;8(6):483-e70.

26 Ellinger JJ, Lewis IA, Markley JL. Role of aminotransferases in glutamate metabolism of human erythrocytes. J Biomol NMR. 2011 Apr;49(3-4):221-9.

27 Flores-Solís LM, Hernández-Domínguez JL. Cardiac troponin I in patients with chronic kidney disease stage 3 to 5 in conditions other than acute coronary syndrome. Clin Lab. 2014;60(2):281-90.

28 Rich JD, Shah SJ, Swamy RS, Kamp A, Rich S Inaccuracy of Doppler echocardiographic estimates of pulmonary artery pressures in patients with pulmonary hypertension: implications for clinical practice. Chest. 2011 May; 139(5):988-93. 